\title{
Long-Term Ecohydrologic Monitoring: A Case Study from the Santee Experimental Forest, South Carolina
}

\author{
Devendra M. Amatya ${ }^{1 *}$ and Carl C. Trettin ${ }^{1}$
}

AUTHORS: ${ }^{1}$ Research Hydrologist and Team Leader/Soil Scientist, USDA Forest Service, Cordesville, SC 29434.

*devendra.m.amatya@usda.gov

\begin{abstract}
Long-term research on gauged watersheds within the USDA Forest Service's Experimental Forest and Range (EFR) network has contributed substantially to our understanding of relationships among forests, water, and hydrologic processes and watershed management, yet there is only limited information from coastal forests. This article summarizes key findings from hydrology and water-quality studies based on long-term monitoring on first-, second-, and third-order watersheds on the Santee Experimental Forest, which are a part of the headwaters of the east branch of the Cooper River that drains into the harbor of Charleston, South Carolina. The watersheds are representative forest ecosystems that are characteristic of the low-gradient Atlantic Coastal Plain. The longterm (35-year) water balance shows an average annual runoff of $22 \%$ of the precipitation and an estimated $75 \%$ for the evapotranspiration (ET), leaving the balance to groundwater. Non-growing season prescribed fire, an operational management practice, shows no effects on streamflow and nutrient export. The long-term records were fundamental to understanding the effects of Hurricane Hugo in 1989 on the water balance of the paired watersheds that were related to vegetation damage by Hugo and post-Hugo responses of vegetation. The long-term precipitation records showed that the frequency of large rainfall events has increased over the last two decades. Although there was an increase in air temperature, there was no effect of that increase on annual streamflow and water table depths. The long-term watershed records provide information needed to improve design, planning, and assessment methods and tools used for addressing the potential impacts of hydrologic responses on extreme events; risk and vulnerability assessments of land use; and climate and forest disturbance on hydrology, ecology, biogeochemistry, and water supply.
\end{abstract}

\section{INTRODUCTION}

Observations and data from long-term experimental watersheds are the foundation of hydrology as a geoscience (Tetzlaff et al., 2017) and are invaluable for natural resource and environmental planning and management (Bosch et al., 2007). This understanding was the basis for establishing gauged watersheds on many experimental forest and agricultural settings in the 1960s, which have advanced knowledge on hydrologic processes and the associated interactions with ecosystem structure and functions (Amatya, Campbell, Wohlgemuth et al., 2016; Vose et al., 2014). Historically, long-term hydrologic records have proved critical for flood forecasting, water conservation and management, agricultural and drought planning, and addressing critical environmental and water quality issues (Bosch et al., 2007). Through a series of examples and new analyses, Moran et al. (2008) showed the value of USDA long-term data in understanding key ecohydrological issues, including (1) time lag between causes and effects, (2) critical thresholds and cyclic trends, (3) context of rare and extreme events, and (4) mechanistic feedbacks for simulation modeling. Similarly, Bosch et al. (2007) described studies that evaluated the impacts of agriculture on regional surface and groundwater quality in the long-term Little River Experimental Watershed initiated by the USDA Agricultural Research Service (ARS) Southeast Watershed Research Laboratory (SEWRL) in south-central Georgia, United States, in 1967. Amatya and Trettin (2007) reported the long-term experimental watershed monitoring studies initiated in 1963 by the USDA Forest Service at Santee Experimental Forest (SEF) in Coastal South Carolina (SC), which were recently updated by Amatya, Callahan, and Trettin (2016). Data and information from these collaborative studies provide a "reference" condition for water resources development and management, wetland restoration and conservation, and 


\section{Long-Term Ecohydrologic Monitoring}

improving hydrologic assessment tools for management decisions on this rapidly urbanizing coastal landscape. Similarly, long-term data/studies from high-gradient upland experimental forest watersheds, like the upland conditions of South Carolina, are available from the USDA Forest Service Coweeta Hydrologic Laboratory (https:// www.srs.fs.usda.gov/coweeta/). Furthermore, several recent studies have synthesized data from small paired watersheds, including those in the EFR network, highlighting important insights that can be gained from watershed science and long-term experimental data such as taking societal needs into consideration (Lovett et al., 2007; Vose et al., 2014; Amatya, Campbell, Wohlgemuth et al., 2016; Tetzlaff et al., 2017). Headwater catchments are important because they influence supply, transport, and the fate of water and solutes in downstream receiving waters through their intrinsic connections to landscape hydrologic processes controlling the recharge of subsurface water stores, flow paths, and residence times (Alexander et al., 2007).

Amatya et al. (2009) emphasized a need to extend and strengthen multidisciplinary collaboration, including sustaining and sharing such long-term data from the various ecosystem-wide experimental watersheds maintained by the ARS and the Forest Service, as well as other institutions. Such a collaboration would help develop a platform to better understand the complex ecosystem processes and the interactions and improved methods for quantifying them in the face of changing land use and climate. The goal of this longterm monitoring program is to effectively use the collected data and information in collaborative studies leading to the development/refinement of methods and tools used in predicting and evaluating the effects of both anthropogenic and natural disturbances while also making them publicly available in a timely manner to stakeholders and society for sound management decisions regarding contemporary issues on flooding, drought, water supply, restoration, and other ecosystem services. This paper summarizes the watershed descriptions and the hydro-meteorologic data being collected at the SEF site and synthesizes key research results.

\section{SITE DESCRIPTION}

The SEF was established in 1937 by the USDA Forest Service with a mission of silvicultural research, environmental monitoring, and demonstration, and educational activities in support of sustainable forest management practices of coastal plain forests, such as those within the Francis Marion National Forest (FMNF) near Huger, South Carolina, 50 $\mathrm{km}$ northwest of Charleston. The SEF $\left(33^{\circ} 08^{\prime} 15^{\prime \prime} \mathrm{N}, 79^{\circ}\right.$ $49^{\prime} 0^{\prime \prime} \mathrm{W}$ ) is located within the headwaters of Huger Creek, a tributary of the East Branch of the Cooper River that drains into Charleston Harbor (Figure 1). In order to study the effects of silvicultural practices on hydrology and water quality, gauged watersheds were established beginning in November 1963 with WS77, a first-order watershed of 155 ha, and WS78, a third-order watershed of 5,240 ha (Amatya and Trettin, 2007; Amatya et al., 2015). A second-order watershed (WS79) of 500 ha was gauged in 1966, followed in 1968 by another first-order watershed (WS80) of 206 ha (reduced to 160 ha in late 2001) as a pair to WS77. The monitoring was discontinued in May 1982, resumed in November 1989 soon after the passage of Hurricane Hugo, and continues to the present day. The forest was heavily impacted by the hurricane in 1989 (Hook et al., 1991), and its current vegetation consists of pine and pine mixed with hardwood stands that have been vigorously re-growing since this tropical storm. Soils in SEF are predominantly Alfisols and Ultisols (SCS 1980), primarily somewhat-poorly to poorly drained sandy loams with clayey subsoils with high surface water retention capacity and low permeability. The climate of the site is subtropical with long, hot summers followed by short, warm, and humid winters, with an average annual temperature and potential evapotranspiration (PET) of $18.3^{\circ} \mathrm{C}$ and $1135 \mathrm{~mm}$, respectively, as well as an average annual precipitation of $1370 \mathrm{~mm}$ (Dai et al., 2013). Some more details are given below in the Additional Information section.

\section{HYDRO-METEOROLOGIC MEASUREMENTS}

Rainfall amounts on the watersheds and the SEF headquarters (SHQ) have been collected using automatic gauges backed up with manual measurements since 1946 (Table 1). Stream stage and flow rates are being measured continuously using sensors/dataloggers upstream of compound V-notch weirs on the WS77, WS80, and WS79 watersheds, while using the sensor for stage and area-velocity method for the WS78 watershed (Figure 1; Table 1). Complete weather parameters (e.g., temperature, humidity, solar and net radiation, wind speed and direction) are measured at the SHQ and WS78, as well as above the forest canopy on WS80. Only precipitation, air, and soil temperature data are collected at the MET station on the WS77 and WS80 watersheds. (Table 1). Automatic and manual measurements of water table levels are made in groundwater wells in a network across the watersheds. Water samples for water quality analysis are collected manually as well as on a flow proportional basis using automatic samplers at each of the flow gauging stations (Figure 1). Details of all hydro-meteorologic and water quality measurements, including for the historic periods, are given in Table 1 and elsewhere (Amatya and Trettin, 2007; Harder et al., 2007; Jayakaran et al., 2014; Amatya et al., 2015; Muwamba et al., 2016). Hydrology, climate, water quality, and geospatial data are available at: http://cybergis. uncc.edu/santee, and most recently transitioning to https:// www.fs.usda.gov/rds/archive/catalog/. Rain and flow data 
for the third-order watershed (WS78) can also be accessed at: https://waterdata.usgs.gov/sc/nwis/uv?site_no $=02172035$, a USGS site, on a real time basis. Real time climatic data from the SEF headquarters is also available using SMART FOREST web portal at (https://smartforests.org/content/ smart-forests-data).

\section{SYNTHESIZED STUDY RESULTS}

\section{HYDROLOGY AND FLOODING}

Streamflow rates and volumes, primarily driven by shallow groundwater on these watersheds, are highly responsive to rainfall with their significant $(p<0.01)$ correlation with monthly rainfall (Dai et al., 2013). Streamflow rates are also influenced by vegetation and topography. Flooding resulting from surface runoff and rapid subsurface drainage occurred only during extreme storm events. Baseflow from the system was highly variable. On average, $20-25 \%$ of the annual rainfall (P) became streamflow (Q), although it varied from $6 \%$ to $59 \%$, depending on seasonal soil moisture storage. An exponential increase of runoff for storm events occurred when the water table level was near or above the surface. (Young and Klawitter, 1968; Amatya et al., 2006; Harder et al., 2007; Jayakaran et al., 2014). For example, the extreme precipitation event of October 3-4, 2015, with > $500 \mathrm{~mm}$ rainfall in two days with already wet soil moisture conditions, flooded much of the experimental forest site and the surrounding areas (Amatya, Harrison, and Trettin, 2016).

Storm hydrograph analyses using long-term data from historic (for WS78) and recent (for WS80) periods showed the event runoff coefficient $(\mathrm{Q} / \mathrm{P})$ varying from $1-74 \%$, with a mean of $34 \%$ for the first-order WS 80 , and $1-80 \%$, with a mean of $25 \%$ for the third-order WS78 watersheds, respectively (La Torre Torres et al., 2011; Epps et al., 2013a). Variability in event runoff was attributed to seasonal trends in water table elevation fluctuation as regulated by evapotranspiration (Epps et al., 2013a). The authors also reported that the 5- and 30-day antecedent precipitation index (API) for the site, determined by summing the rain amount for 5 and 30 days, respectively, prior to the event, did not have direct effect on storm event stream discharge, but indirectly through the water table position as affected by infiltration and ET. These results indicate that in lowgradient coastal zone watersheds with shallow water tables, stormflow response to rainfall occurs more or less uniformly throughout the watershed, as opposed to variable source area concepts in upland hillslope processes.

Analysis of shallow (up to $3 \mathrm{~m}$ deep) and deep well (14.5 m deep) water table measurements at WS78 watershed provided an average recharge estimate to the surficial aquifer of 114 $\pm 60 \mathrm{~mm} \mathrm{y}-1$ (Callahan et al., 2012). The main factor influencing recharge estimates was antecedent water table level, which in turn was influenced by landscape position and soil texture. The shallow water table conditions at this site support a large range of natural wetlands and create management challenges across the region (Callahan et al., 2017). Modest changes in the position of the water table can lead to either groundwater flooding and concomitant management challenges for silvicultural activities, or to ecosystem stresses related to dry conditions in wetlands during times of below-normal precipitation or as a result of groundwater withdrawal. Dai et al. (2013) found a significant increase $(p<0.02)$ in annual mean water table elevation on the first-order watersheds due to an increase in rainfall for 1964-1993, which was also true for the current period (2003-2017). However, analyses of annual mean water table records data for that period showed no trend (Amatya, Chescheir, et al., 2019).

\section{WATER QUALITY}

Long-term water quality data (Table 1) showed an average dissolved organic nitrogen (DON) of $\sim 0.7 \mathrm{mg} / \mathrm{L}$, which was 10 -fold higher than dissolved inorganic nitrogen (DIN). Phosphate $\left(\mathrm{PO}_{4}-\mathrm{P}\right)$ concentrations averaged 0.028 $\mathrm{mg} / \mathrm{L}$ and declined slightly with increased flow. These concentrations were consistent with data from other black water streams draining southeastern forested watersheds dominated by conifers (Chescheir et al., 2003). However, DIN and $\mathrm{PO}_{4}-\mathrm{P}$ showed much higher variability than DON, indicating a need to understand the processes that affect the dissolved $\mathrm{N}$ and $\mathrm{P}$ export dynamics.

Earlier studies showed that hydrologic fluxes of nitrogen, phosphorus, sulfur, and basic cations to groundwater and stream water from pine understory treated by winter prescribed burns are not likely to affect stream-water quality (Richter et al., 1982, 1983). The streamflow nutrient concentrations in those studies were generally much lower than for agricultural or urban land use (Binkley, 2001; Amatya et al., 2006, 2007; Muwamba et al., 2016). Trettin et al. (2019) synthesized environmental monitoring and studies at the SEF that are relevant to water quality within the lower Coastal Plain, where forested wetlands-often impacted by hurricanes and tropical storms-strongly influence water quality through hydrological and biogeochemical processes. For example, Wilson et al. (2006) reported an increase of $\mathrm{N}$ and $\mathrm{P}$ exports by $108-154 \%$, primarily due to increased outflows, soon after Hurricane Hugo in 1989. The authors also noted that the reference watershed provides a good, reliable baseline for conditions of minimal human disturbance that may be useful in developing water quality criteria, TMDL modeling, and permitting.

\section{CLIMATE VARIABILITY AND EXTREME EVENTS}

Dai et al. (2013) summarized the long-term climatic data developed on the SEF for the period of 1946-2008, which 


\section{Long-Term Ecohydrologic Monitoring}

showed an increase in mean annual air temperature at a rate of $0.19^{\circ} \mathrm{C}$ per decade, which is higher than the global mean rate of $0.17^{\circ} \mathrm{C}$ for the same period. This is somewhat consistent with a recent study by Mizzell et al. (2014) reporting a steady temperature increase since the 1970s, but a decreasing trend from the 1950s through the 1960s, indicating a spatial variability in trend for the 66 stations the authors analyzed.

Total annual precipitation has not changed significantly over the period of 1946-2008 (Dai et al., 2013), which is consistent with Mizzell et al. (2014). However, large storm events (> 25 and $>50 \mathrm{~mm}$ precipitation) have increased by 13 and $21 \%$, respectively, over the 63 -year period (Dai et al., 2013), and that perspective is consistent with an updated analyses using data from 2003-2015 (Amatya, Harrison, and Trettin 2016). Maximum hourly design rainfall for various return periods derived from intensity-duration-frequency analysis is often used in designing culvert sizes and other storm water management structures on forest lands. Tian et al. (2019) used the annual maximum hourly rainfall intensity at the WS80 site for the 1976-2015 period obtained by combining measured data from the nearby Lotti gauge for 1976-1994, Charleston airport data from 1995-2002, and the Met 25 gauge on the WS80 itself from 2003-2015. The authors found the design rainfall intensity at the WS 80 to be higher than the interpolated published values by the NOAA for the site location for all rainfall durations, except for $1 \mathrm{hr}$. This indicates that NOAA-based maximum intensity values may underestimate peak discharges needed for storm water design practices at the WS80 site, although the onsite data may also have some uncertainties due to data gap fillings and extrapolation. Similarly, the authors also reported flood frequency estimates for the site using its long-term measured annual maximum flow rates and showed that a widely used Rational Method may underestimate the peak discharge for large storm events on watersheds of this size. Such information can be a better representation for on-site design of storm water management structures on the WS80 and other similar sites nearby.

Streamflow on WS80 and the adjacent treatment watershed WS77 increased to as much as 50\% of the rainfall soon after Hugo, with greatly increased flow from the WS77 that was salvage logged (Sun et al., 2000; Amatya et al., 2006). This was likely due to decreased vegetative water use on both watersheds due to loss of tree canopy. An established relationship of monthly outflows between the paired watersheds for the pre-Hugo period (1969-1981), with higher outflows from the WS77 than the WS80, continued for three years after Hugo (1989); however, it reversed in 1993 and did not return to pre-Hugo levels for 10 years, until 2004 (Figure 2) (Jayakaran et al., 2014). The authors attributed this result to a catastrophic change in forest vegetation due to selective hurricane damage, with one watershed recovering to pre-hurricane levels of evapotranspiration at a quicker rate due to the greater abundance of pine seedlings and saplings in that watershed. This data indicates both the hydrologic resiliency of these coastal forests and the importance of longterm monitoring.

Although the SEF has experienced a number of hurricanes and tropical storms during its history that were characteristic of the coastal systems, the 2-day rainfall of nearly $500 \mathrm{~mm}$ from October 3-4, 2015 (indirect effect of Hurricane Joaquin) was the historic record, consistent with rainfall records from stations and associated floods across the State of South Carolina reported by Mizzell et al. (2016) for October 1-5, 2015. As a result, Amatya, Harrison, and Trettin (2016) reported the peak discharge of $17.4 \mathrm{~m}^{3} \mathrm{~s}^{-1}$, which exceeded the previously measured (October 24, 2008) record of $3.8 \mathrm{~m}^{3} \mathrm{~s}^{-1}$ on WS80, equivalent to 500 -year return period estimates. This provides insights for a need to revisit existing approaches for hydrologic design of forest cross drainage and other water management structures as concerns about extreme storm events resulting from global warming continue, as suggested by Tian et al. (2019) and Walega et al. (2019).

\section{MODEL DEVELOPMENT, TESTING/APPLICATION}

Long-term monitoring also provided the data to test strengths and limitations of hydrology and water quality models of various complexities (e.g., SWAT, MIKESHE, DNDC, DRAINMOD, SCS-CN) as applied on these lowgradient coastal forest watersheds, as well as to develop new tools. Dai, Li, et al. (2010) conducted a calibration and validation of a watershed-scale distributed hydrologic model (MIKESHE) using both the daily water table and streamflow for the 2003-2008 period for WS80. The modeling results demonstrated that the streamflow and water table depth were sensitive to the model input parameters, especially to surface detention storage, drainage depth, soil hydraulic properties, plant root depth, and surface roughness. Model assessment results showed that, compared to current climate conditions, the annual average streamflow increased by $2.4 \%$, with $1 \%$ increase in rainfall, and decreased by $2.4 \%$, with a $1 \%$ decrease in rainfall. A quadratic polynomial relationship between changes in water table level and rainfall was found (Dai, Trettin, et al., 2010; Dai et al., 2011). The simulated annual average water table level and streamflow linearly decreased with an increase in temperature within the range of temperature change scenarios $\left(0-6^{\circ} \mathrm{C}\right)$. Although MIKESHE is a fully process-based model, it requires a large quantity of resources and time for its hydrologic applications. Recently, Amatya, Fialkowski, and Bitner (2019) tested a simple 4-parameter empirical model to compute daily water table depths for poorly drained forested lands, with its potential application in assessing wetland hydrology used in restoration purposes. 
Amatya and Jha (2011) tested the refined SWAT model with an improved single-parameter "depletion coefficient" for plant evapotranspiration in the SCS curve number $(\mathrm{CN})$ for WS78 for predicting daily and seasonal flow. Better predictions were found for wetter years than drier years. The predictions of days with zero flow were also in agreement with the measured data. This clearly indicates a need for longterm data capturing seasonal climatic variability for a reliable model validation. However, the refined model was unable to accurately capture the flow dynamics and time to peak for events preceded by saturated conditions during the dry summer and wet winter, warranting further investigations on these shallow soil forest systems. One possible reason for discrepancy was the use of published values of Manning's roughness parameter in flow routing in stream channels with vegetation. The importance of accounting for friction caused by interaction between the main channel and vegetated areas in discharge prediction was recently studied by MirosławŚwiątek and Amatya $(2012,2017)$. The authors demonstrated a $10-32 \%$ increase in frictional coefficient when the variability in vegetation stem diameter was considered.

Using a 3-year (2008-2011) period of rainfall and runoff storm event data from the WS80 watershed (Figure 1) to compare with another coastal site in SC, Epps et al. (2013a) found that runoff generation from storm events was strongly related to water table elevation consistent with Harder et al. (2007), where seasonally variable wet and dry moisture conditions persist. For that matter, stream runoff predictions using the classic $\mathrm{CN}$ model for these watersheds do not compare closely to measured outflow under the average moisture conditions. However, results show improvement in flow predictions using CNs adjusted for antecedent runoff conditions and water table position (Epps et al., 2013b). In a similar study using modification of the soil water retention parameter in the CN model, Wałęga et al. (2017) found better predictions of storm runoff events on WS80 compared to the classic SCS-CN method, consistent with Blair et al. (2012). Most recently, Walega et al. (2019) successfully tested a modified version of the widely used SCS-CN based SME model and SCS TR-55 graphical peak discharge methods for predicting runoff and peak discharge, respectively, for selected storm events from the WS80 watershed for 20112015 period. Additional study is underway to further test these SCS CN methods with data from multiple forest sites.

\section{PERSPECTIVES}

This article synthesizes various hydrologic studies conducted at Santee Experimental Forest in South Carolina, the only coastal plain experimental forest with long-term hydrology and water quality data on paired forest watersheds in the Southeast. A key finding of the synthesis was that if this monitoring system, discontinued in 1981, had not been revitalized soon after Hurricane Hugo in 1989, there would have been no way of knowing about the reversal in the flow relationships between the paired watersheds three years after Hugo, which, as shown in Figure 2, was attributed to post-Hugo changes in vegetation type and growth dynamics that impacted ET. The return to pre-disturbance baseline relationship indicates hydrologic resiliency of these coastal

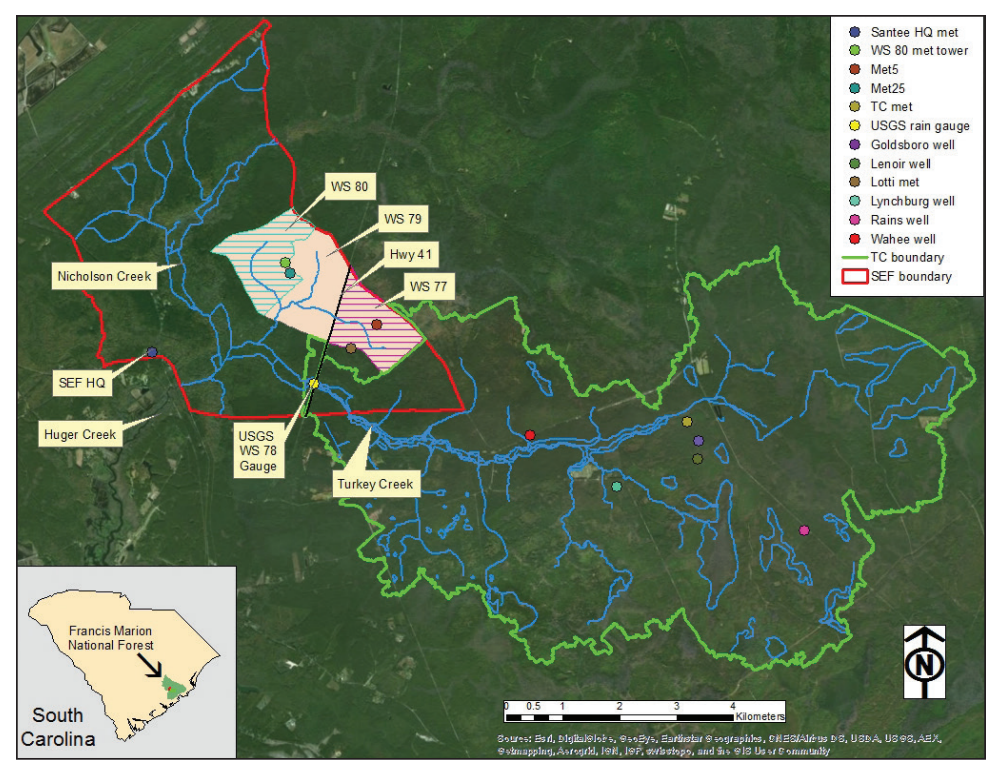

Figure 1. Location map of experimental watersheds (1st order, 2nd order, and 3rd order) with their hydro-meteorologic stations at Santee Experimental Forest (SEF) (see Table 1) within Francis Marion National Forest, South Carolina. The SEF headquarter (SEF HQ) office location is also shown. TC is Turkey Creek 3rd order watershed. 


\section{Long-Term Ecohydrologic Monitoring}

Table 1. Hydro-meteorologic and water quality parameters monitored during historic and current periods at Santee Experimental Forest headquarter (Santee) and watersheds, SC (See Figure 1 for locations).

\begin{tabular}{|c|c|c|c|c|c|}
\hline Parameters & Santee & First-Order WS77 & First-Order WS80 & $\begin{array}{l}\text { Second-Order } \\
\text { WS79 }\end{array}$ & $\begin{array}{c}\text { Third-Order } \\
\text { WS78 }\end{array}$ \\
\hline \multicolumn{6}{|c|}{ Meteorology (Climate) (http://cybergis.uncc.edu/santee/) } \\
\hline Precipitation & $\begin{array}{l}1946 \text { to date; } \\
\text { Manual/ Pluviometer, } \\
\text { Automatic }\end{array}$ & $\begin{array}{l}\text { 1963-1971; 1990- } \\
\text { 1997; 2001 to date; } \\
\text { Manual/ Automatic }\end{array}$ & $\begin{array}{l}\text { 1990-2000; } 2001 \\
\text { to date; Manual/ } \\
\text { Automatic }\end{array}$ & & $\begin{array}{l}1964-2000 ; 2001 \\
\text { to date; Manual/ } \\
\text { Automatic }\end{array}$ \\
\hline Air Temperature & $\begin{array}{l}\text { 1946- ; Manual/ } \\
\text { Automatic }\end{array}$ & $\begin{array}{l}\text { 2001- Manual/ } \\
\text { Automatic }\end{array}$ & $\begin{array}{l}\text { 2001- Manual/ } \\
\text { Automatic; } 2010 \\
\text { (Canopy), Automatic }\end{array}$ & & $\begin{array}{l}\text { 1971-2000; } \\
2001- \\
\text { Automatic }\end{array}$ \\
\hline Humidity & $\begin{array}{l}\text { 2001- ; Manual/ } \\
\text { Automatic }\end{array}$ & & $\begin{array}{l}2010 \text { (Canopy), } \\
\text { Automatic }\end{array}$ & & $\begin{array}{l}2005- \\
\text { Automatic }\end{array}$ \\
\hline Solar Radiation & $\begin{array}{l}\text { 2001- } \\
\text { Manual/ Automatic }\end{array}$ & & $\begin{array}{l}2010 \text { (Canopy), } \\
\text { Automatic }\end{array}$ & & $\begin{array}{l}2005- \\
\text { Automatic }\end{array}$ \\
\hline Net Radiation & $\begin{array}{l}\text { 2001- ; Manual/ } \\
\text { Automatic }\end{array}$ & & $\begin{array}{l}2010 \text { (Canopy), } \\
\text { Automatic }\end{array}$ & & \\
\hline $\begin{array}{l}\text { Wind Speed and } \\
\text { Direction }\end{array}$ & $\begin{array}{l}\text { 2001- Manual/ } \\
\text { Automatic }\end{array}$ & & $\begin{array}{l}2010 \text { (Canopy), } \\
\text { Automatic }\end{array}$ & & $\begin{array}{l}2005- \\
\text { Automatic }\end{array}$ \\
\hline Pan Evaporation & 2004-Manual & & & & \\
\hline Soil Temperature & & 2001-Automatic & 2001-Automatic & & $\begin{array}{l}\text { 2001-2004; } \\
\text { 2005- Auto }\end{array}$ \\
\hline Dry-Wet Deposition & $2008-$ & & & & \\
\hline Ozone & 2008-2012 & & & & \\
\hline \multicolumn{6}{|c|}{ Hydrology (http://cybergis.uncc.edu/santee/) } \\
\hline Shallow Water Table & & $\begin{array}{l}\text { 1964-191; 1992-1995; } \\
2005 \text { to date; Manual/ } \\
\text { Automatic }\end{array}$ & $\begin{array}{l}\text { 1992-1995; } 2003 \\
\text { to date; Manual/ } \\
\text { Automatic }\end{array}$ & & $\begin{array}{l}2006-2019 \\
\text { Manual/ } \\
\text { Automatic }\end{array}$ \\
\hline $\begin{array}{l}\text { Deep Groundwater } \\
\text { (College of Charleston) }\end{array}$ & & & $\begin{array}{l}2004 \text { to date; } \\
\text { Manual/ Automatic }\end{array}$ & & $\begin{array}{l}2004 \text { - to } \\
\text { date; Manual/ } \\
\text { Automatic }\end{array}$ \\
\hline Stream Gauge Stage & & $\begin{array}{l}\text { 1964-1981; 1989- } \\
2000 ; 2003-\end{array}$ & $\begin{array}{l}1968-1981 ; 1989- \\
1999 ; 2003-\end{array}$ & $\begin{array}{l}\text { 1966-1973; } \\
\text { 1989-1990; 2002- }\end{array}$ & $\begin{array}{l}\text { 1964-1984; } \\
2005-\end{array}$ \\
\hline Streamflow & & $\begin{array}{l}1963-1981 ; 1989- \\
1999 ; 2003-\end{array}$ & $\begin{array}{l}1968-1981 ; 1989- \\
1999 ; 2003-\end{array}$ & $\begin{array}{l}\text { 1966-1976; } \\
\text { 1989-1990; 2003- }\end{array}$ & $\begin{array}{l}\text { 1964-1984; } \\
2005-\end{array}$ \\
\hline Soil Moisture & & 2018- Automatic & 2012- Automatic & & \\
\hline \multicolumn{6}{|c|}{ Water Quality (http://cybergis.uncc.edu/santee/) } \\
\hline $\begin{array}{l}\text { Nutrients }(\mathrm{NO} 3+\mathrm{NO} 2, \\
\mathrm{NH} 4, \mathrm{TKN}, \mathrm{TDN}, \mathrm{PO} 4 \\
\mathrm{TP})\end{array}$ & & $\begin{array}{l}\text { 1976-1982; 1989- } \\
\text { 1994; Manual grab } \\
\text { 2003- Automatic }\end{array}$ & $\begin{array}{l}\text { 1976-1982; 1989- } \\
\text { 1994; Manual grab } \\
\text { 2004- Automatic }\end{array}$ & $\begin{array}{l}\text { 1989-1994; } \\
\text { Manual grab } \\
\text { 2006-; Automatic }\end{array}$ & $\begin{array}{l}\text { 2006-; Manual } \\
\text { grab/Automatic }\end{array}$ \\
\hline Cations & & Same as above & Same as above & & \\
\hline DOC & & 2004- Auto & 2004- Auto & 2006- Auto & 2006- Auto \\
\hline Temperature & & 2006- Manual & 2006-Manual & 2006- Manual & 2006-Manual \\
\hline Dissolved O2 & & 2006- Manual & 2006- Manual & 2006- Manual & 2006-Manual \\
\hline Conductivity & & 2006- Manual & 2006-Manual & 2006- Manual & 2006-Manual \\
\hline Salinity & & 2006- Manual & 2006- Manual & 2006- Manual & 2006-Manual \\
\hline $\mathrm{pH}$ & & 2006- Manual & 2006-Manual & 2006- Manual & 2006- Manual \\
\hline
\end{tabular}


forests after a hurricane event. These results are invaluable because information on the influence of extreme climate events in natural ecosystems is limited (as these events are rare), but there is a pressing need to identify how these events change ecosystem processes to explore new hypotheses and improve our predictive capabilities.

The SEF is likely the only coastal plain forest station with long-term net radiation measurements (Table 1) in the Southeast as part of the climatic data database. That data was invaluable for developing a calibration factor for estimating net radiation from solar radiation from other weather stations in South Carolina in a recent study, funded by the SC Department of Natural Resources, on investigating the assessment of PET for its application in water use and management planning for the state of South Carolina (Amatya, Muwamba, et al., 2018). The long-term hydrology data from the control watershed in the paired system can be used as a "reference" for "pre-development" scenario design/ analysis on developing/urbanizing lands. Some of its data was used in the 3-D modeling study of Charleston Harbor for the dissolved oxygen TMDL (Lu et al., 2005; TetraTech, 2008), and possibly for wetland restoration in the coastal region. Long-term data and hydrological and water quality models developed and successfully tested with these data at this freshwater forested wetland site upstream of tidally mediated riparian systems can also be helpful in impact assessment of land use and climate change. The long-term data also contributed to short-term studies focused on understanding various hydrological, biogeochemical, and transport processes on this poorly drained coastal forest (Young and Klawitter, 1968; Richter et al., 1982; 1983; Harder et al., 2007; Callahan et al., 2012; Epps et al., 2013a; Griffin et al., 2014; Amatya and Harrison, 2016).

The importance and value of long-term experimental data for scientific research and for science-based sound management decisions on issues of societal concern such as water supply, flooding, drought management, ecosystem restoration, and quality of water bodies are being widely publicized (Tetzlaff et al., 2017; Moran et al., 2008; Trettin, Amatya, Gaskins et al., 2019). Furthermore, there has been increasing interest for use of such data and information on a real-time basis for prompt decision-making processes. The long-term experimental sites maintained by the USDA Agricultural Research Service and the USDA Forest Service are a leading example of databases that offer multidecadal observations and cross-ecosystem studies. (Amatya et al., 2016; Moran et al., 2008). These studies, Tetzlaff et al. (2017) emphasized, offer a crucial evidence base for understanding and managing the provision of clean water supplies, predicting and mitigating the effects of floods, and protecting ecosystem services provided by streams, rivers, and wetlands. Long-term studies at the SEF site, which is representative of rapidly urbanizing areas near the coastal/tidal waters and riparian buffers become even more crucial because of an ongoing threat of high intensity storms and sea level rise (Williams et al., 2019). Adequate resources are critical for securing high quality long-term data from successful multipurpose monitoring for proper management of land and water in an integrated, sustainable way (Lovett et al., 2007; Tetzlaff et al., 2017).

\section{ACKNOWLEDGMENTS}

Andy Harrison, Hydrologic Technician, and Julie Arnold, Biological Technician, both at USDA Forest Service, Santee Experimental Forest; Francis Marion National Forest; College of Charleston; US Geological Survey; University of North Carolina Charlotte; Clemson University; North Carolina State University; University of North Georgia; University of Agriculture in Krakow and Warsaw University of Life Sciences, both in Poland; University of New Hampshire.

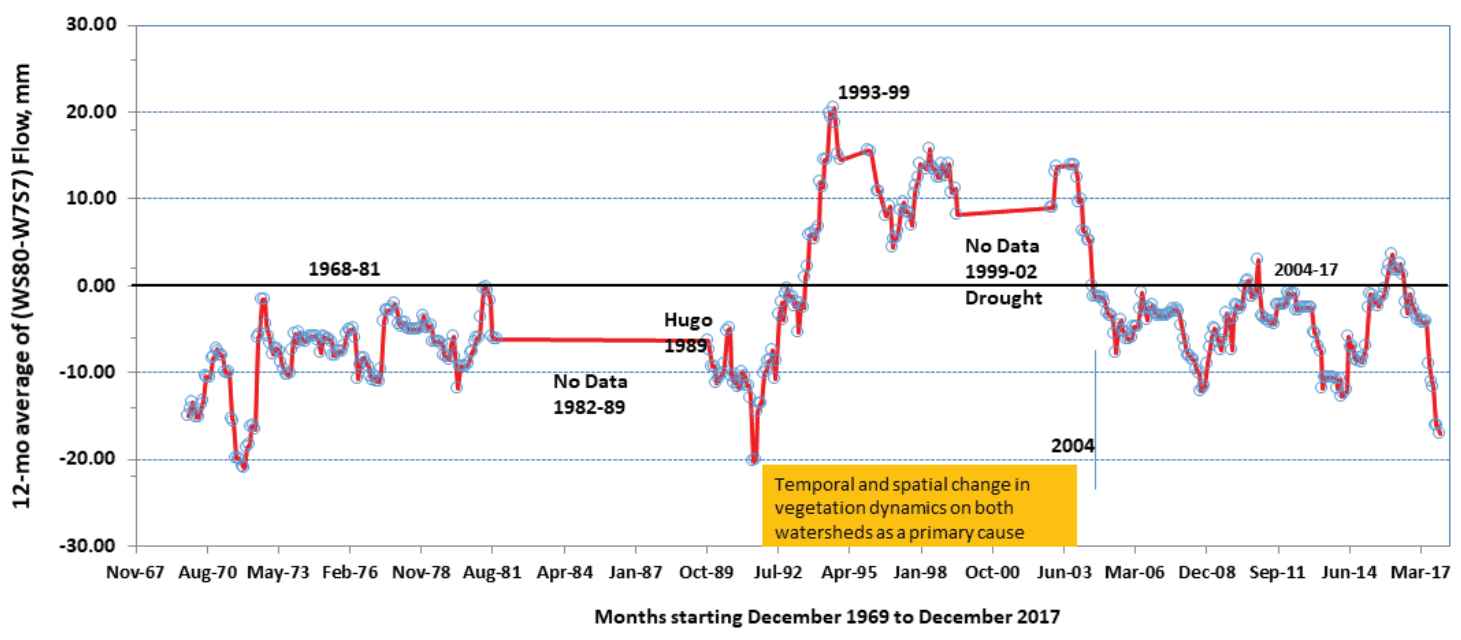

Figure 2. Twelve-month moving average of difference of monthly flow between the WS77 and WS80 watersheds from December 1969 to December 2017. Horizontal lines indicate gaps due to (1) discontinuity in monitoring between 1981 and 1989 and (2) missing data during 1999 and 2002 also with drought (modified after Amatya et al., 2011). 


\section{Long-Term Ecohydrologic Monitoring}

\section{REFERENCES}

Alexander RB, Boyer EW, Smith RA, Schwartz GE, Moore RB. 2007. The role of headwater streams in downstream water quality. J Amer Water Resou Assoc. 43(1):41-59.

Amatya DM, Miwa M, Harrison CA, Trettin CC, Sun G. 2006. Hydrology and water quality of two first order forested watersheds in Coastal South Carolina (Paper Number 062182). Paper presented at the ASABE Annual International Meeting, Portland, OR.

Amatya DM, Trettin CC. 2007. Development of watershed hydrologic research at Santee Experimental Forest, Coastal South Carolina. In: Furniss MJ, Clifton CF, Ronnenberg KL, editors. Advancing the fundamental sciences: proceedings of the Forest Service National Earth Sciences Conference: volume 1 (General Technical Report PNW-GTR-689), San Diego. Portland (OR): USDA Forest Service, Pacific Northwest Research Station, p. 180-190.

Amatya DM, Harrison CA, Trettin CC. 2007. Water quality of two first-order forested watersheds in Coastal South Carolina. In: Watershed management to meet water quality standards and TMDLS (total maximum daily load): proceedings of the 10-14 March 2007, San Antonio, Texas. St. Joseph (MI): ASABE; p. 507-515.

Amatya DM, Skaggs RW, Trettin CC. 2009. Advancing the science of forest hydrology: a challenge to agricultural and biological engineers. Resou Mag, 16(5):10-11.

Amatya DM, Jha MK. 2011. Evaluating SWAT model for a low gradient forested watershed in Coastal South Carolina. Trans of the ASABE, 54(6):2151-2163.

Amatya DM, Trettin CC, Williams TM. 2011. Sources of errors in assessing potential water balance in lowgradient coastal watersheds. Invited abstract H53E-1467 presented at: 2011 Fall Meeting, AGU, December 5-9; San Francisco, CA.

Amatya DM, Callahan TJ, Hansen WF, Trettin CC, RadeckiPawlik A, Meire P. 2015. Turkey Creek-a case study of ecohydrology and integrated watershed management in the low-gradient Atlantic Coastal Plain, U.S.A. J of Water Resoue and Protec, 7(10):792-814.

Amatya DM, Harrison CA. 2016. Grass and forest potential evapotranspiration comparison using 5 methods in the Atlantic Coastal Plain. J of Hydrol Engrg. 21(5):1-13. Amatya DM, Campbell J, Wohlgemuth P, Elder K, et al. 2016. Hydrologic processes of reference watersheds at USDA Forest Service EFRs. In: Amatya DM, Williams TM, Bren L, de Jong C, editors. Forest hydrology: processes, management, and applications. Oxfordshire (UK): CABI Publishers, p. 219-239.

Amatya DM, Callahan TJ, Trettin CC. 2016. Synthesis of 10 years of studies on Turkey Creek watershed. In: Stringer CE, Krauss KW, Latimer JS, editors. Headwaters to estuaries: advances in watershed science and management: proceedings of the 5th interagency conference on research in the watersheds (General Technical Report SRS-211). Asheville (NC): USDA Forest Service, Southern Research Station, p. 22-33.
Amatya DM, Harrison CA, Trettin CC. 2016. Hydrometeorologic assessment of October 2015 extreme precipitation event on Santee Experimental Forest watersheds, SC. Journal of South Carolina Water Resources, 3(1):19-30.

Amatya DM, Fialkowski M, Bitner A. 2019. A daily water table depth computing model for poorly drained soils. Wetlands, 39(1):39-54. https://doi.org/10.1007/s13157018-1069-7.

Amatya DM, Muwamba A, Panda S, Callahan TJ, Harder S, Pellett SA. 2018. Assessment of spatial and temporal variation of potential evapotranspiration estimated by four methods for South Carolina. Journal of South Carolina Water Resources, 5(1):3-24.

Amatya DM, Chescheir GM, Williams TM, Skaggs RW. 2019. Long-term water table dynamics of forested wetlands: drivers and their effects on wetland hydrology in the Southeastern Atlantic Coastal Plain. Wetlands. https://doi.org/10.1007/s13157-019-01153-y.

Binkley D. 2001. Patterns and processes of variation in nitrogen and phosphorus concentrations in forested streams (Technical Bulletin Number 836). Research Triangle Park (NC): National Council for Air and Stream Improvement, Inc.

Blair AC, Sanger DM, White DL, Holland AF, Vandiver LA, Bowker C, White S. 2012. Quantifying and simulating stormwater runoff in watersheds. Hydrol Proc. 28(3):559569. https://doi.org/10.1002/hyp.9616.

Bosch DD, Sheridan JM, Lowrence RR, Hubbard RK, Strickland TC, Feyereisen GW, Sullivan DG. 2007. Little River Experimental Watershed Database. Water Resou Res. 43(9). https://doi.org/10.1029/2006WR005844.

Callahan TJ, Amatya DM, Stone P. 2017. Coastal forests and groundwater: using case studies to understand the effects of drivers and stressors for resource management. Sustainability, 9(3), 447.

Callahan TJ, Vulava VM, Passarello MC, Garrett CG. 2012. Estimating groundwater recharge in lowland watershed. Hydrol Proc, 26(19):2845-2855.

Chescheir GM, Lebo ME, Amatya DM, Hughes JE, Gilliam JW, Skaggs RW, Herrmann RB. 2003. Hydrology and water quality of forested lands in eastern North Carolina (Technical Bulletin 320). Raleigh (NC): NC State University.

Dai Z, Li C, Trettin CC, Sun G, Amatya DM, Li H. 2010. Bicriteria evaluation of the MIKE SHE model for a forested watershed on the South Carolina coastal plain. Hydrol Earth Syst Sci. 14:1033-1046.

Dai Z, Trettin CC, Li C, Amatya DM, Sun G, Li H. 2010. Sensitivity of stream flow and water table depth to potential climatic variability in a coastal forested watershed. J Amer Wat Resou Assoc. 46(5):1036-1048. https://doi.org/10.1111/j.1752-1688.2010.00474.x.

Dai Z, Amataya DM, Sun G, Trettin CC, Li C, Li H. 2011. Climate variability and its impact on forest hydrology on South Carolina Coastal Plain of USA. Atmosphere, 2(3):330-357. https://doi.org/10.3390/atmos2030330. 
Dai Z, Trettin CC, Amatya DM. 2013. Effects of climate variability on forest hydrology and carbon sequestration on the Santee Experimental Forest in Coastal South Carolina (General Technical Report SRS-172). Asheville (NC): USDA Forest Service, Southern Research Station.

Epps T, Hitchcock D, Jayakaran AD, Loflin D, Williams TM, Amatya DM. 2013a. Characterization of storm flow dynamics of headwater streams in the South Carolina lower Coastal Plain. J Amer Water Resou Assoc. 49(1):76-89. https://doi.org/10.1111/JAWR.12000.

Epps T, Hitchock DR, Jayakaran A, Loflin DR, Williams TM, Amatya DM. 2013b. Curve number method assessment for watersheds draining two headwater streams in lower Coastal Plain of South Carolina, USA. J Amer Water Resou. 49(6):1284-1295. https://doi. org/10.1111/jawr.12084

Griffin MP, Callahan TJ, Vulava VM, Williams TJ. 2014. Influence of soil type and antecedent soil moisture conditions on storm-event flow pathways in lower coastal plain watersheds of the southeastern United States. Water Resou Res. 50(10):8265-8280. https://doi. org/10.1002/2014WR015941.

Harder SV, Amatya DM, Callahan TJ, Trettin CC, Hakkila J. 2007. Hydrology and water budget for a first-order forested Atlantic Coastal Plain watershed, South Carolina. J Amer Water Resou Assoc. 43(3):563-575. https://doi. org/10.1111/j.1752-1688.2007.00035.x.

Hook DD, Buford MA, Williams TM. 1991. Impact of Hurricane Hugo on the South Carolina Coastal Plain forest. J of Coastal Research, Special Issue 8: 291-300. Jayakaran A, Williams TM, Ssegane HS, Amatya DM, Song B, Trettin CC. 2014. Hurricane impacts on a pair of coastal forested watersheds: implications of selective hurricane damage to forest structure and streamflow dynamics. Hydrol Earth Syst Sci. 18(3):1151-1164. https://doi.org/10.5194/hess-18-1151-2014.

La Torre Torres I, Amatya DM, Callahan TJ, Sun G. 2011. Seasonal rainfall-runoff relationships in a lowland forested watershed in the Southeastern USA. Hydrol Process. 25(13):2032-2045. https://doi.org/10.1002/ hyp.7955.

Lovett DM, Burns DA, Driscoll CT, Jenkins JC, Mitchell MJ, Rustad L, Shanley JB, Likens GE, Haeuber R. 2007. Who needs environmental monitoring? Frontiers in Ecol and the Environ. 5(5):253-260. https://doi.org/10.1890/15409295(2007)5[253:WNEM]2.0.CO;2

Lu S, Amatya DM, Miller J. 2005. Development of watershed and reference loads for a TMDL in Charleston Harbor System, SC. In: Gassman PW, editor. Proceedings of the third conference on watershed management to meet water quality standards and emerging TMDL. ASABE Paper \# 701P0105. St. Joseph, MI.

Mirosław-Świątek D, Amatya DM. 2012. Determination of plant characteristics used in discharge capacity assessment of Turkey Creek watershed on South Carolina coastal plain, USA. Land Reclam. 43(2):121-134. https:// doi.org/10.2478/v10060-008-0098-y.
Mirosław-Świątek D, Amatya DM. 2017. Effects of cypress knee roughness on flow resistance and discharge estimates of the Turkey Creek watershed. Land Reclam. 49(3):179-199. https://doi.org/10.1515/sggw-2017-0015.

Mizzell H, Malsick M, Abramyan I. 2014. South Carolina's climate report card: understanding South Carolina's climate trends and variability. J of South Carolina Water Resou. 1(1):4-9. https://doi.org/10.34068/01.01.

Mizzell H, Malsick M, Tyler W. 2016. The historic South Carolina rainfall and major floods of October 1-5, 2015. J of South Carolina Water Resou. 3(1):3-7. https://doi. org/10.34068/JSCWR.03.01.

Moran MS, Peters DPC, McClaran MP, Nichols MH, Adams MB. 2008. Long-term data collection at USDA experimental sites for studies of ecohydrology. Ecohydrology, 1(4):377-393. https://doi.org/10.1002/ eco.24.

Muwamba A, Amatya DM, Trettin CC, Glover J. 2016. Comparing nutrients export from first, second, and third order watersheds at South Carolina Atlantic Coastal Plain. In: Stringer CE, Krauss KW, Latimer JS, editors. Headwaters to estuaries: advances in watershed science and management: proceedings of the 5th interagency conference on research in the watersheds (General Technical Report SRS-211). Asheville (NC): USDA Forest Service, Southern Research Station, p. 83-88.

Richter DD, Ralston CW, Harms WR. 1982. Prescribed fire: effects on water quality and forest nutrient cycling. Science, 215(4533):661-663. https://doi.org/10.1126/ science.215.4533.661.

Richter DD, Ralston CW, Harms WR. 1983. Chemical composition and spatial variation of bulk precipitation at a coastal plain watershed in South Carolina. Water Resou Res. 19(1):134-140. https://doi.org/10.1029/ WR019i001p00134.

SCS. 1980. Soil survey of Berkeley County, South Carolina. Washington (DC): USDA Soil Conservation Service.

Sun G, Lu J, Gartner D, Miwa M, Trettin CC. 2000. Water budgets of two forested watersheds in South Carolina. In: Proceedings of the Spring Specialty Conference, American Water Resources Association. Middleburg (VA): American Water Resources Association, p. 199-202.

TetraTech. 2008. 3-D modeling report for the Charleston Harbor System: a final report prepared by Jordan, Jones, and Goulding for the Berkeley-Charleston-Dorchester Council of Governments. Atlanta (GA): TetraTech.

Tetzlaff D, Carey SK, McNamara JP, Laudon H, Soulsby C. 2017. The essential value of long-term experimental data for hydrology and water management. Water Resour Res. 53(4):2598-2604. https://doi. org/10.1002/2017WR020838.

Tian S, Amatya DM, Marion D, Caldwell P, Panda S, Laseter S, Youssef M, Cheseir GM, Sun G, et al. Forthcoming 2019. Comparisons among design flood discharges estimated from historical records, USGS Regional Equations, and the Rational Method for four small forested watersheds. In Review J Hydrol Engrg. 


\section{Long-Term Ecohydrologic Monitoring}

Trettin CC, Amatya DM, Gaskins T, Miniat CF, Chow A, Callahan T. 2019. Watershed Response to Longleaf Pine Restoration - Application of Paired Watersheds on the Santee Experimental Forest. In: Proceedings of the Sixth Interagency Conference on Research in the Watersheds. July 23-26, 2018, Shepherdstown, WV. e-Gen. Tech. Rep. SRS-243. Asheville, NC: U.S. Department of Agriculture Forest Service, Southern Research Station. 211 p.

Trettin CC, Amatya DM, Muwamba A, Glover J, Wenerick W. Forthcoming 2019. Ecoregion 8.5.3 Southern Coastal Plain: Santee Experimental Forest, South Carolina. In: Ryan D, editor. Biological responses to stream nutrients: a synthesis of science from experimental forests and ranges. Washington (DC): Pacific Northwest Station, USDA Forest Service.

Vose JM, Swank WT, Adams MB, Amatya DM, Campbell J, Johnson S, Swanson FJ, Kolka R, Lugo AE, Musselman $\mathrm{R}$, Rhoades C. 2014. The role of experimental forests and ranges in the development of ecosystem science and biogeochemical cycling research. In: Hayes DC, Stout SL, Crawford RH, Hoover AP, editors. USDA Forest Service Experimental Forests and Ranges. New York (NY): Springer, p. 387-403. https://doi.org/10.1007/978-1-46141818-4_17.

Wałęga AA, Cupak A, Amatya DM, Drożdżal E. 2017. Comparison of direct outflow calculated by different methods for mountainous and highland catchments in Upper Vistula basin, Poland and lowland catchment in South Carolina, USA. Acta Sci Pol Formatio Circumiectus, 16(1):187-207. https://doi.org/10.15576/ ASP.FC/2017.16.1.187.

Walega A, Amatya DM, Caldwell P, Marion D, Panda S. 2019. Assessment of Storm Direct Outflow and Peak Flow Rates using Improved SCS-CN Models for Selected Forested Watersheds in the Southeastern United States. Journal of Hydrology - Regional Studies, 27 (2020) 100645.

Williams TM, Amatya DM, Conner W, Panda S, Xu G, Dong J, Trettin C, Dong C, Gao X, Shi H, Yu K, Wang H. 2019. Freshwater-Tidal Forested Wetlands (TFW): Tidal Forested Wetlands: Mechanisms, Threats, and Management Tools. In Chapter 6, Wetlands: Ecosystem Services, Restoration and wise use. Ecological Studies series 238, Eds. S. An and J. Verhoeven, pp:129-158 Springer.

Wilson L, Amatya DM, Callahan TJ, Trettin CC. 2006. Hurricane impact on stream flow and nutrient exports for a first-order forested watershed of the lower Coastal Plain, South Carolina. In: Second Interagency Conference on Research on Watersheds: March 16-18, 2006. Otto (NC): Coweeta Hydrologic Laboratory.

Young CE Jr, Klawitter RA. 1968. Hydrology of wetland forest watersheds. In: Proceedings of CUCOH Hydrology Conference, March 28-29, 1968. Clemson (SC): Clemson University, p. 29-38.

\section{ADDITIONAL INFORMATION}

\section{WATERSHED CHARACTERISTICS}

1. Three gauged watersheds on moderately well to very poorly drained soils of lower Atlantic Coastal Plain: WS80 (control): 200 ha until 2001; 160 ha after 2001-first order; WS77 (treatment): 155 ha-first order; WS79: 500 ha-second order, all tributaries of Turkey Creek within the East Cooper River Basin; and WS78 (Turkey Creek): 5240 ha-third order

2. Surface elevations: $2.0-14.0 \mathrm{~m}$ a.m.s.l.; < $1 \%$ slope

3. Dominant soils (Wahee, Craven, Lenoir, Meggett) characterized by seasonally high water tables

4. Vegetation-Loblolly pine, Longleaf pine, Cypress and Sweet gum

\section{WATERSHED MONITORING (ALSO REFER TO TABLE 1)}

- Daily rainfall and temperature only at Santee Experimental Forest Head Quarters (since 1946)

- All other complete automatic Campbell Scientific weather and HOBO Met stations (Table 1)

- Flow gauging stations at the outlets of WS77, WS80, and WS79 that accumulate flows from both WS77 and WS 80 since 1964 (Water stages measured by Doppler and WL16 pressure transducer with an ISCO 4210 logger); (Table 1)

- Automatic groundwater table recorders on WS77, WS80, and WS78 (GL16s)

- Manual PVC ground water table wells (Scattered on WS77 and WS80)

- HYDRA soil moisture monitoring on WS77 and ACCLIMA soil moisture monitoring on WS80

- Flow proportional water quality sampling stations at WS 77, WS80, and WS78 gauge outlets (ISCO 4210 sampler)

- Stream water physical parameters by Hanna multiparameter meter (Manta probes earlier)

- Throughfall measurement gauges on WS80 (Texas Electronics) (2003-2004)

- Dry and wet deposition monitoring using Aerochem Metrics Precipitation Collector at Santee Experimental Forest HQ

- Carbon and Greenhouse gas monitoring

- Ozone monitoring at Santee Experimental Forest (Discontinued in 2012)

- Tree growth monitoring (Height, dbh, LAI) on WS80 and WS77 